\title{
Diseminasi Teknik Budikdamber Lele untuk Produksi Pangan Skala Rumah Tangga Selama Pandemi Covid-19
}

\author{
Mojiono $^{1}$, Nur Qomariah², Fortunata Riana ${ }^{2}$ \\ 1,2 Universitas Trunojoyo Madura, Indonesia
}

\begin{abstract}
A B S T R A C T
CATFISH MINICULTURE OFTEN CALLED AS "BUDIKDAMBER" HAS RAPIDLY GAINED ITS POPULARITY DURING COVID-19 PANDEMIC DUE TO FOLLOWING REASONS: EASY TO ADOPT AND AFFORDABLE. In this regard, we disseminated technical assistance of "budikdamber" to villagers in two villages: Montongsekar and Sugihwaras, which aimed at fostering the food production in households. The dissemination was carried out through three activities: (1) assembly of "budikdamber" unit, (2) assistance and observation, and (3) evaluation. The unit was assembled using 80 L-plastic container, and filled with about $60 \mathrm{~L}$ of freshwater. Catfish seeds $(12 \mathrm{~cm}$ in length) were reared in the unit for 3 weeks. During the period, their growth (body length, in $\mathrm{cm}$ ) and survival rate. At the end of period, questionnaires were asked to the participants. The results showed that "budikdamber" unit could be made simply, equipped with water outlet, allowing to change water without jeopardizing fish survival. The assistance and observation to the participants demonstrated a pivotal role in disseminating the technical aspects of the catfish miniculture. The aquculture of catfish using "budikdamber" resulted in a satisfying output, represented by high survival rate ranging from $94-100 \%$ and final fish size (16.82 - $17.90 \mathrm{~cm})$. For further consideration, we need to publicize the fish culture method using both offline and online approaches, enabling to deliver the benefits of this technique to broader scale. In conclusion, "budikdamber" could impose significant effect on our attempts in ensuring food security during covid-19 pandemic.
\end{abstract}

Keywords: Budikdamber, Catfish Miniculture, Covid-19 Pandemic, Food Security.

\begin{tabular}{llll}
\hline Received: & Revised: & Accepted: & Available online: \\
19.03 .2020 & 03.06 .2020 & 14.08 .2020 & 30.11 .2020 \\
\hline
\end{tabular}

\section{Suggested citation:}

Mojiono, Qomariah, N., \& Riana, F. (2020). Diseminasi teknik Budikdamber Lele untuk produksi pangan skala rumah tangga selama pandemi Covid-19. Jurnal Pengabdian Pada Masyarakat, 5(4), 917-926. https://doi.org/10.30653/002.202054.594

Open Access I URL: http://ppm.ejournal.id/index.php/pengabdian/article/view/594

\footnotetext{
1 Corresponding Author: Program Studi Teknologi Industri Pertanian, Fakultas Pertanian, Universitas Trunojoyo Madura, Indonesia. Email: mojiono@trunojoyo.ac.id
} 


\section{PENDAHULUAN}

Covid-19 menyebabkan krisis kesehatan global dan telah menyebar ke berbagai belahan dunia. Wabah ini telah menyebar dengan sangat cepat dan menyebabkan efek luas secara ekonomi maupun sosial. Hingga 20 Agustus 2020, data World Health Organization (WHO) memperlihatkan jumlah kasus global mencapai 22.256.202 dengan 782.456 kematian (WHO, 2020). Kendati menjadi problem serius pada bidang kesehatan, efek covid-19 nyatanya telah menjalar ke sektor lain, termasuk pangan. Khusus di sektor pangan, di awal masa pandemi, International Food Policy Research Institute (IFPRI) telah melaporkan bahwa belum ada tanda-tanda signifikan terhadap kelangkaan pangan dan kenaikan harga yang drastis (Vos, Martin, \& Laborde, 2020). Meskipun demikian, perhatian serius pada ketahanan pangan selama pandemi tetap harus dilakukan; sebagaimana yang terjadi pada pandemi sebelumnya (SARS dan MERS), persitiwa tersebut memicu kenaikan harga pangan dan terjadinya market panics di beberapa area terdampak (Vos, Martin, \& Laborde, 2020). Belum lagi di masa pandemi, diperkirakan sekitar sepertiga penduduk dunia sedang dalam protokol ketat kunci tara atau lockdown; kondisi ini menyebabkan disrupsi saluran distribusi pangan (Galanakis, 2020). Adanya kebijakan lockdown di berbagai wilayah perkotaan juga akhirnya meningkatkan kesadaran terhadapnya pentingnya konsep urban agriculture; mereka yang tinggal di perkotaan menjadi rentan kesulitan pangan saat krisis global melanda (Pulighe \& Lupia, 2020). Singkatnya, ancaman food insecurity terus meningkat, sehingga langkah-langkah strategis perlu dilakukan sebagai upaya antisipasi.

Seiring dengan meningkatnya seruan untuk memperkuat ketahanan pangan, para peneliti telah berupaya melakukan respon cepat melalui berbagai inovasi, misalnya optimalisasi lahan pekarangan untuk produksi pangan (Swardana, 2020), serta pengerahan ketersediaan pangan hewani asal ternak melalui pemanfaatan berkelanjutan Sumberdaya Genetik Ternak (Tiesnamurti, 2020). Selain itu, ada satu inovasi yang dipandang tepat untuk diimplementasikan hingga pasca pandemi covid19, yaitu budidaya ikan dalam ember "budikdamber". Umumnya, ikan yang digunakan dalam teknik budidaya ikan ini adalah lele.

Budidaya lele dalam ember menjadi teknik yang cepat populer karena beberapa alasan. Pertama, aktivitas work from home akibat covid-19 menumbuhkan trend "bertani di rumah". Kedua, budikdamber lele tidak membutuhkan keterampilan khusus. Perawatan yang mudah membuat aktivitas budikdamber bisa dilakukan oleh banyak orang dan praktis. Ketiga, lele adalah komoditas perikanan yang sudah sangat populer. Keempat, biaya yang diperlukan untuk pembuatan unit budikdamber relative terjangkau. Bahkan beberapa komponen dapat digantikan dengan barang-barang bekas. Selain itu, wadah budidaya ikan yang digunakan mudah didapatkan, hemat dalam penggunaan air serta tambahan penanaman sayuran kangkung untuk memenuhi kebutuhan sayuran (Nursandi, 2018).

Montongsekar dan Sugihwaras adalah dua lokasi yang dipilih sebagai desa untuk diseminasi teknik budikdamber lele. Desa Montongsekar ada di Kabupaten Tuban, sedangkan Desa Sugihwaras ada di Kabupaten Nganjuk. Secara umum, karakteristik kedua desa memiliki kesamaan, yaitu dominasi wilayah pertanian. Meski demikian, budikdamber dapat dilakukan dengan optimasi lahan/ruang di rumah. Abdimas di 
desa ini bertujuan untuk meningkatkan pemahaman serta memberi kesempatan kepada masyarakat untuk melakukan praktik budikdamber lele.

\section{METODE}

\section{Waktu dan Lokasi}

Kegiatan diseminasi diseminasi teknik budikdamber lele dilakukan selama 4 pekan pada Juli 2020. Lokasi kegiatan yaitu yaitu Desa Montongsekar Kecamatan Montong Kabupaten Tuban (lokasi 1) dan Desa Sugihwaras Kecamatan Ngluyu Kabupaten Nganjuk (lokasi 2). Kedua lokasi berada di wilayah Provinsi Jawa Timur dan secara ringkas ditunjukkan pada Gambar 1.

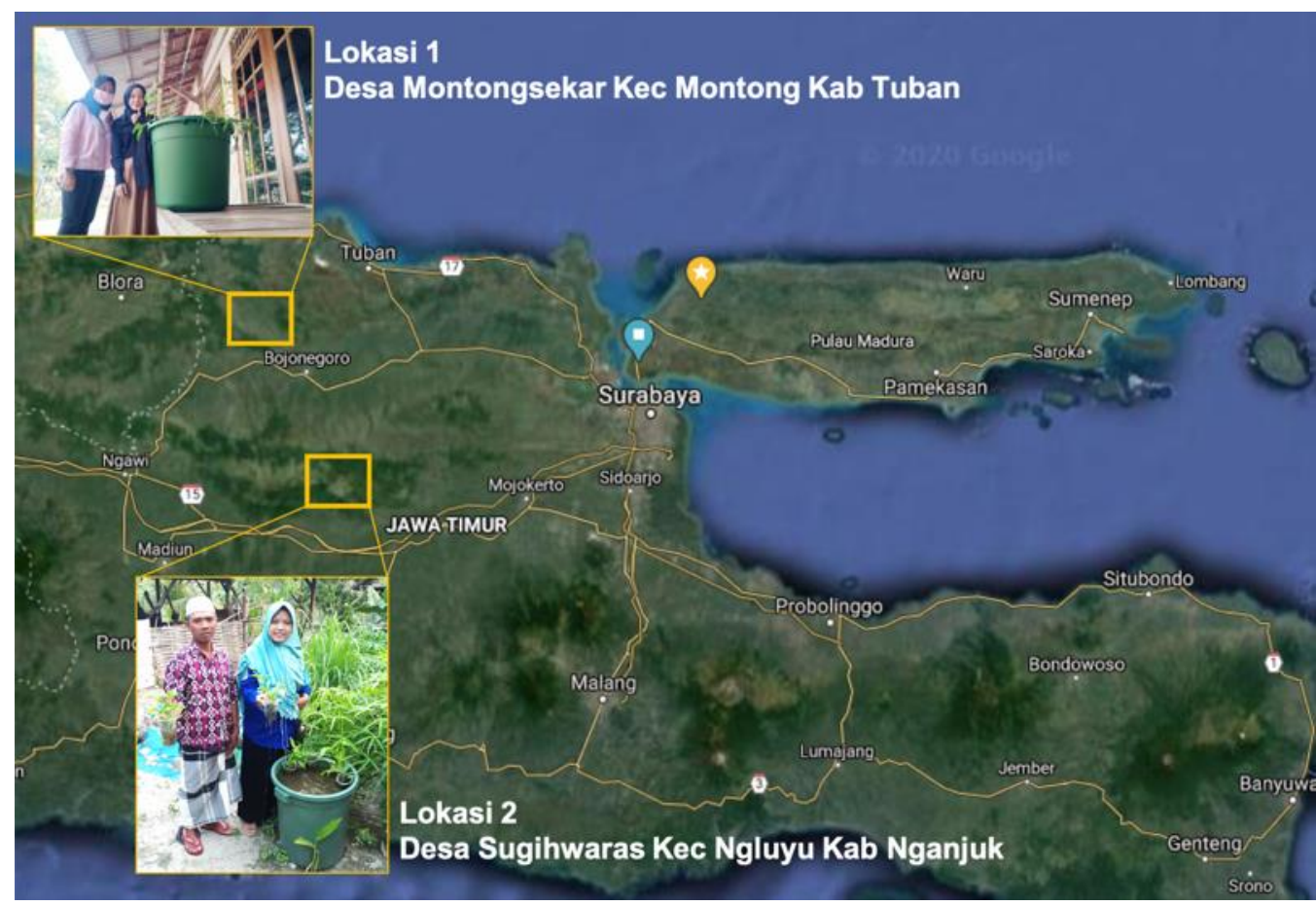

Gambar 1. Lokasi diseminasi teknik budikdamber lele

Sumber: Peta diperoleh dari Google Map, diakses pada 10 Agustus 2020

\section{Pembuatan Unit Budikdamber}

Unit budikdamber dibuat dengan bahan dan alat sederhana (Tabel 1). Total unit budikdamber yang dibuat adalah 4 unit, yaitu dua unit (unit 1 dan 2) untuk lokasi 1 dan dua unit (unit 3 dan 4) untuk lokasi 2. Secara ringkas, ember dilubangi di bagian samping bawah untuk tempat kran air. Kran air akan digunakan untuk pembuangan air. Satu unit ember diisi oleh kurang lebih 60 liter air dan 50 ekor bibit lele. Selanjutnya, gelas plastik (10-15 buah) diikat ke bibir ember menggunakan kawat, sebagai tempat budidaya kangkung. Pemilihan kangkung sebagai sayur budidaya dalam budikdamber ini didasarkan pada karakteristiknya, yakni mudah tumbuh, perawatan mudah, dan bisa dimanfaatkan untuk beragam bahan baku masakan berbahan sayur. 
Tabel 1. Alat dan bahan utama yang digunakan untuk pembuatan unit budikdamber lele

\begin{tabular}{ll}
\hline Alat dan bahan & Spesifikasi dan kegunaan \\
\hline Ember & Volume 80 liter, wadah untuk budidaya \\
Gelas plastik & $\begin{array}{l}\text { Kapasitas } 500 \mathrm{~mL} \text {, wadah untuk media pertumbuhan kangkung } \\
\text { Kawat }\end{array}$ \\
$\begin{array}{l}\text { Tidak ada spesifikasi khusus, untuk mengikat gelas plastik ke } \\
\text { ember }\end{array}$ \\
Kran air & Tidak ada spesifikasi khusus, untuk saluran pembuangan air \\
Bibit lele & Ukuran $\pm 12 \mathrm{~cm}$ \\
Bibit kangkung & Tidak ada spesifikasi khusus \\
\hline
\end{tabular}

\section{Pendampingan, Observasi dan Evaluasi}

Setelah unit budikdamber diberikan kepada warga, tim abdimas melakukan pendampingan. Pendampingan dimaksudkan untuk memberi informasi kepada warga mengenai teknik pemeliharaan serta menyelesaikan permasalahan selama proses budidaya berlangsung. Selama pendampingan, pertumbuhan lele diamati secara intensif sebanyak 3 kali pengamatan, dimulai setelah 1 minggu lele dimasukkan ke unit budikdamber. Pengamatan pertumbuhan lele difokuskan pada dua parameter utama: panjang tubuh ikan (dalam satuan $\mathrm{cm}$, diukur menggunakan mistar) dan survival rate, yaitu persentase jumlah lele yang bertahan hidup selama masa pengamatan. Pengukuran panjang lele dilakukan secara sampling sebanyak 5 ekor.

Selama proses pendampingan, tim abdimas memberikan kuesioner evaluasi kepada warga penerima manfaat sebagai responden. Kuesioner berisi 3 pertanyaan (Tabel 2) untuk mengetahui tingkat pemahaman warga mengenai konsep budikdamber, metode pembelajaran budikdamber yang paling diminati dan kebermanfaatan budikdamber. Data hasil pengamatan pertumbuhan lele dan kuesioner diolah dan disajikan secara deskriptif.

Tabel 2. Kuesioner untuk evaluasi kegiatan abdimas

\begin{tabular}{ll}
\hline Pertanyaan & Jawaban \\
\hline P1: Sebelum kegiatan abdimas, apakah anda & a. Tidak paham \\
paham mengenai konsep budikdamber? & b. Sedikit paham \\
& c. Paham \\
P2: Apa metode penyampaian teknik & d. Sangat paham \\
budikdamber yang anda sukai? & a. Penyuluhan \\
& b. Bagi-bagi unit \\
P3: Seberapa banyak manfaat yang diterima & c. Tutorial daring \\
dari program abdimas ini? & d. Lainnya \\
& a. Tidak bermanfaat \\
& c. Sedikit bermanfaat \\
& d. Sangat bermanfaat \\
\hline
\end{tabular}




\section{HASIL DAN PEMBAHASAN}

\section{Unit budikdamber}

Gambar 2 memperlihatkan beberapa dokumentasi hasil diseminasi budikdamber lele. Secara umum, proses penyampaian informasi budikdamber kepada masyarakat berlangsung lancar. Hal ini disebabkan oleh karakter budikdamber sendiri yang memang sangat aplikatif, mudah diterapkan oleh masyarakat luas. Beberapa modifikasi unit budikdamber bisa dilakukan, menyesuaikan dengan kondisi masyarakat dan tentu saja kreativitas mereka. Contoh modifikasi yang bisa dilakukan misalnya penggunaan tutup ember sebagai tempat gelas plastik media akuaponik.

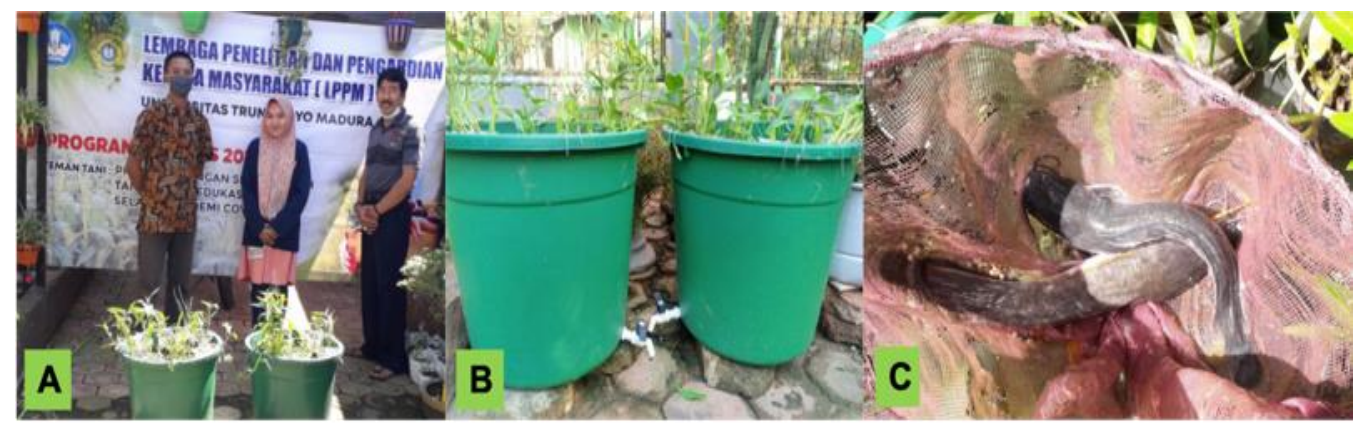

Gambar 2. Dokumentasi tim budikdamber lele (A), dua unit budikdamber (B) dan lele hasil budikdamber $(C)$

Untuk performa budikdamber, Nursandi (2018) telah melaporkan hasil eksperimen budikdamber lele. Ikan yang digunakan adalah lele. Benih lele (ukuran $\pm 7 \mathrm{~cm}$ ) ditebar pada ember volume 78 liter. Ember diisi air setinggi $50 \mathrm{~cm}$ atau setara 60 liter. Setiap 1 ember berisi 60 benih lele (densitas 1 ekor lele per liter).

Budikdamber lele sejatinya bisa menghasilkan manfaat ganda sekaligus, yakni produksi lele dan sayuran melalui sistem akuaponik. Sejauh ini, kangkung adalah sayuran akuaponik yang paling popular diintegrasikan dengan budikdamber lele karena beberapa karakteristiknya: (1) benih/bibit mudah diperoleh dengan harga terjangkau, (2) mudah dirawat dan (3) produktivitas tinggi. Kangkung juga sangat mudah diolah menjadi pangan siap konsumsi seperti tumis kangkung.

Keuntungan sistem budikdamber yang dipadukan dengan budidaya kangkung melalui akuaponik dirancang mempunyai keunggulan lain, yaitu tidak membutuhkan listrik seperti yang biasa digunakan pada sistem resirkulasi akuaponik yang ada di masyarakat (Febri, Alham, \& Afriani, 2019; Nursandi, 2018). Dengan sejumlah keunggulan ini, diseminasi teknik budikdamber sebaiknya perlu diperluas, sehingga semakin banyak masyarakat yang ikut memanfaatkan teknik budidaya ini, kendati hasilnya hanya untuk konsumsi sendiri.

\section{Pendampingan dan observasi}

Warga penerima manfaat budikdamber ini mendapatkan pendampingan dari tim. Melalui pendampingan budidaya, mereka memiliki kesempatan untuk menyampaikan kesulitan ataupun kondisi aktual budidaya. Kehadiran tim abdimas untuk memberi pendampingan budidaya menjadi sangat penting karena seluruh warga penerima 
manfaat ini tidak memiliki pengalaman di bidang budidaya perikanan. Transfer pengetahuan dan keterampilan budidaya ini akan membantu keberlangsungan praktik budikdamber, tidak hanya saat ini, namun juga di masa mendatang.

Selain pendampingan, observasi oleh tim abdimas juga dilakukan yang difokuskan pada pertumbuhan dan kelangsungan hidup (survival rate) lele. Indikator pertumbuhan lele adalah ukuran ikan. Pertumbuhan lele dalam unit budikdamber diamati 1 kali per minggu yang dilakukan selama 3 minggu. Pengamatan pertama dimulai dari 1 minggu setelah lele ditempatkan di unit budikdamber.

Gambar 3 memperlihatkan perubahan panjang ikan selama 3 kali observasi. Secara umum, lele di seluruh unit budikdamber menunjukkan tren yang serupa, yaitu mengalami kenaikan panjang ikan, kecuali pada unit 1 yang sempat mengalami stagnasi pertumbuhan. Stagnasi bisa disebabkan oleh variasi pertumbuhan lele dalam 1 unit budikdamber. Dalam 1 unit, ukuran lele bisa sangat beragam, dari yang kecil hingga besar. Oleh karena itu, selain panjang ikan, parameter lain yang bisa digunakan untuk obervasi pertumbuhan lele adalah berat. Observasi pada parameter berat ikan tidak dilakukan dalam abdimas ini karena pertimbangan ketersediaan alat. Meski demikian, panjang ikan sebagai parameter pertumbuhan sudah cukup merepresentasikan dinamika pertumbuhan lele dalam unit budikdamber.
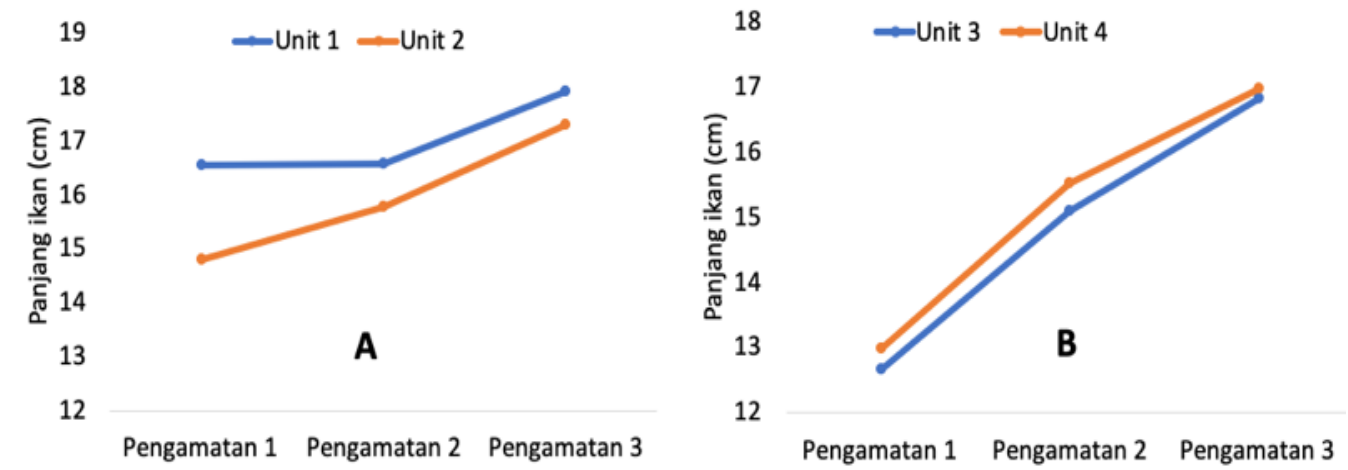

Gambar 3. Dinamika pertumbuhan lele di unit budikdamber lokasi 1 (A) dan lokasi 2 (B)

Survival rate merupakan salah parameter kunci untuk mengevaluasi efektivitas suatu metode budidaya (Zhang et al., 2011). Dari aspek daya tahan hidup, seluruh unit budikdamber memperlihatkan survival rate yang sangat baik, mencapai $100 \%$, kecuali pada unit 4 (98\%). Survival rate 100\% menunjukkan bahwa seluruh ikan dalam unit mampu bertahan hidup selama periode budidaya.

Keberhasilan budidaya ikan dipengaruhi oleh banyak faktor, diantaranya yang paling signifikan adalah kualitas air (Zhang et al., 2011). Parameter kualitas air yang umum digunakan dalam budidaya lele adalah oksigen terlarut, temperatur, turbiditas, pH dan amonia (Hastuti \& Subandiyono, 2014). Kualitas air memiliki peran vital karena berdampak pada aktivitas metabolisme ikan, sehingga upaya menjaga kualitas air perlu dilakukan antara lain dengan penerapan biofilter akuaponik (Wicaksana, Hastuti, \& Arini, 2015). Dalam abdimas ini, guna menjaga kualitas air, penggantian air dilakukan tiap 1 minggu dengan cara membuka kran air, dan menggantinya dengan air baru. Penggantian air dimaksudkan untuk mengurangi stres pada ikan sebagai dampak menurunnya kualitas air akibat akumulasi kotoran dan debris (sisa pakan). 
Penggantian air secara teratur diperlukan untuk menjaga kualitas air, namun masih menyisakan kendala yang tidak bisa diabaikan. Kendala tersebut muncul ketika budidaya lele dilakukan di tempat dengan suplai air yang sangat terbatas. Untuk antisipasi kesulitan ini, adopsi teknologi biofloc bisa dipertimbangkan untuk dilakukan pada budidaya lele tanpa ganti air. Hastuti \& Subandiyono (2014) meneliti efektivitas teknologi biofloc budidaya ikan lele dumbo (Clarias gariepinus, Burchell). Hasil penelitian ini menunjukkan bahwa teknologi biofloc mampu meningkatkan produksi ikan, meningkatkan efisiensi pemanfatan pakan, memperbaiki nilai konversi pakan, memperbaiki kualitas air media serta meningkatkan angka kelangsungan hidup ikan. Oleh karena itu, penelitian teknologi biofloc pada sistem budikdamber perlu dilakukan sehingga memungkinkan masyarakat untuk produksi lele tanpa penggantian air.

\section{Evaluasi kegiatan}

Gambar 4 memperlihatkan rekapitulasi jawaban kuesioner dari responden. Untuk P1, semua responden menjawab "tidak paham", yang mengindikasikan bahwa mereka belum mengetahui konsep budikdamber. Hal ini bisa dipahami karena masyarakat memiliki akses yang berbeda terhadap informasi. Dengan demikian, metode penyampaian informasi teknik budikdamber menjadi faktor esensial. Aspek inilah yang kemudian ditanyakan di P2.

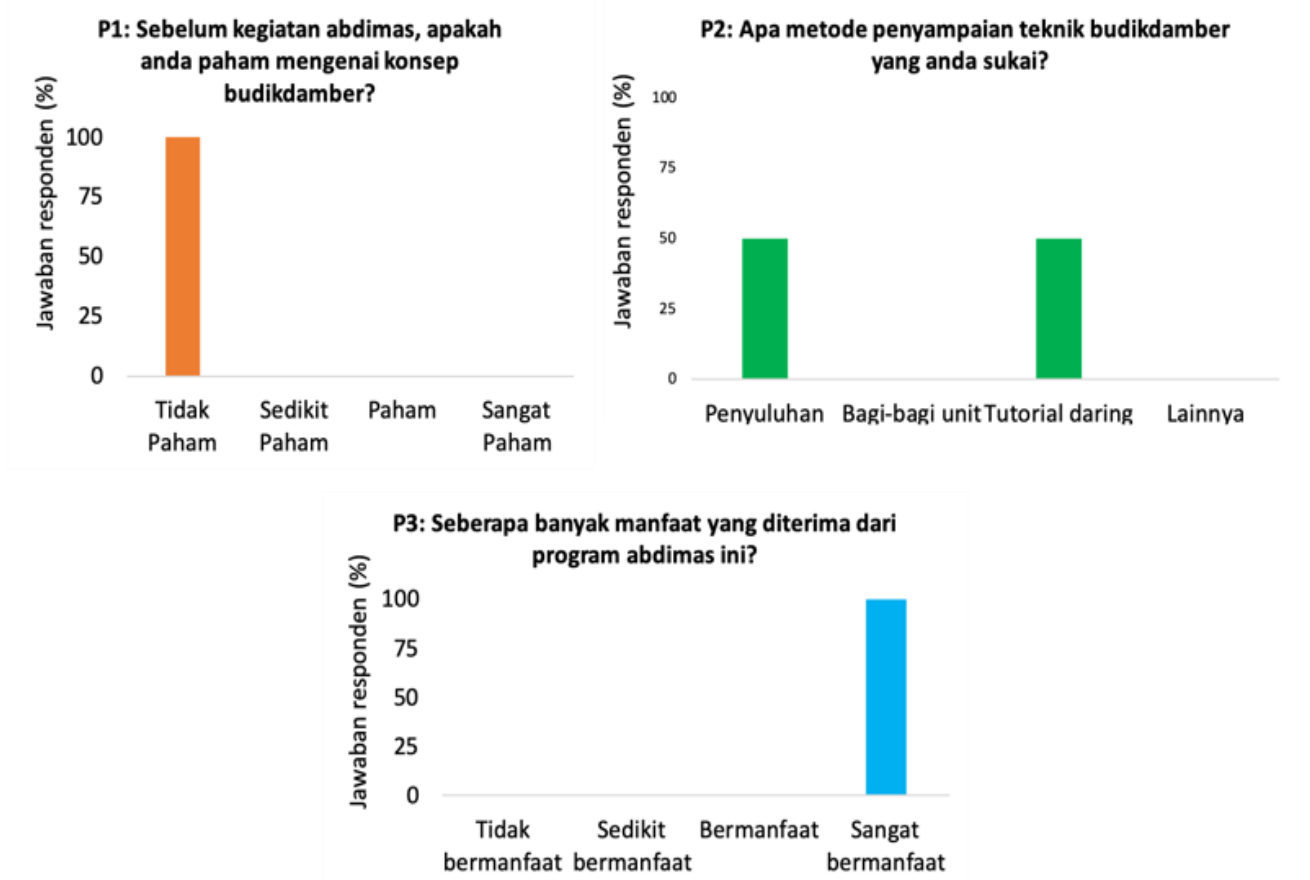

Gambar 4. Respon penerima manfaat terhadap kegiatan diseminasi teknik budikdamber lele

Pada P2, metode "penyuluhan" dan "tutorial daring" masing-masing mendapatkan porsi $50 \%$. Metode "penyuluhan" seperti yang dilakukan di program abdimas ini dipandang sesuai dengan kebutuhan masyarakat yang lebih menyukai tatap muka langsung. Keunggulan metode ini adalah transfer pengetahuan dan aplikasinya bisa langsung dirasakan oleh masyarakat. Hanya saja, karena abdimas berlangsung dalam 
masa pandemi, maka jumlah warga yang terlibat dibatasi. Metode "tutorial daring" atau online juga sangat potensial dilakukan di masa sekarang ini, apalagi masih dalam suasana pandemi. Sebagian masyarakat saat ini sudah memiliki akses internet yang mudah, sehingga konsep "tutorial daring" ini bisa dimanfaatkan oleh mereka.

Terakhir, pada P3, responden ditanyai mengenai kebermanfaatan program abdimas. Hasilnya, seluruh responden menyatakan bahwa abdimas ini "sangat bermanfaat". Teknik budikdamber dirasakan sangat bermanfaat karena dapat diimplementasikan dengan mudah dan biaya yang terjangkau.

Berikutnya, budikdamber bisa dikembangkan tidak hanya untuk produksi pangan skala rumah tangga, namun sebagai unit bisnis. Hanya saja, untuk tujuan usaha, maka ada variabel yang harus diperhatikan agar bisnis tersebut feasible. Fauziah, Agustina, \& Hariyati (2016) melakukan studi kelayakan usaha budidaya lele dengan metode konvensional, bertujuan mengkaji faktor-faktor yang diduga memengaruhi pendapatan. Faktor-faktor tersebut mencakup biaya benih, biaya pakan, jumlah produksi, harga jual, biaya tenaga kerja, biaya vitamin dan obat-obatan, dan luas kolam. Diantara faktor tersebut, pakan menjadi salah satu variabel yang memiliki korelasi negatif dengan tingkat pendapatan, dengan koefisien regresi -1.066. Penggunaan pakan alternatif yang lebih murah bisa menjadi opsi yang signifikan untuk menekan biaya produksi, sehingga berdampak pada meningkatnya pendapatan.

\section{SIMPULAN}

Kegiatan abdimas dengan topik diseminasi teknik budikdamber lele dilakukan di dua desa, Desa Montongsekar di Kabupaten Tuban (lokasi 1) dan Desa Sugihwaras di Kabupaten Nganjuk (lokasi 2). Diseminasi dudidaya lele berhasil dilakukan oleh masyarakat, ditunjukkan dengan tingginya survival rate dan stabilitas pertumbuhan lele. Selain itu, budikdamber lele juga dipadukan dengan budidaya kangkung secara akuaponik untuk produksi sayuran. Pendampingan secara rutin kepada warga penerima manfaat mampu berperan efektif dalam transfer informasi dan keterampilan budikdamber. Dari evaluasi kegiatan, informasi budikdamber lele masih perlu disebarluaskan baik dengan metode penyuluhan langsung ke masyarakat sasaran (secara luring) maupun dengan metode video tutorial (secara daring), sehingga semakin banyak masyarakat yang bisa memanfaatkan teknik budidaya ini.

\section{Ucapan Terima Kasih}

Penulis menyampaikan terima kasih kepada Lembaga Penelitian dan Pengabdian kepada Masyarakat (LPPM) Universitas Trunojoyo Madura atas pendanaan melalui skema ABDIMAS 2020 Nomor 172/UN46.4.1/PM.01.01/2020.

\section{REFERENSI}

Fauziah, A. F., Agustina, T., \& Hariyati, Y. (2017). Analisis pendapatan dan pemasaran ikan lele dumbo di Desa Mojomulyo Kecamatan Puger. JSEP (Journal of Social and Agricultural Economics), 9(1), 20-32.. 
Febri, S. P. (2019). Pelatihan BUDIKDAMBER (Budidaya ikan dalam ember) di Desa Tanah Terban Kecamatan Karang Baru Kabupaten Aceh Tamiang. In Prosiding Seminar Nasional Politeknik Negeri Lhokseumawe (112-117). October 2019. Lhokseumawe: Politeknik Negeri Lhokseumawe.

Galanakis, C. M. (2020). The Food systems in the era of the coronavirus (COVID-19) Pandemic Crisis. Foods, 9(4), 1-10.

Hastuti, S., \& Subandiyono. (2014). Performa produksi ikan lele dumbo (Clarias gariepinus, Burch) yang dipelihara dengan teknologi biofloc. Jurnal Saintek Perikanan, 10(1), 37-42.

Nursandi, J. (2018). Budidaya ikan dalam ember "budikdamber" dengan aquaponik di lahan sempit. In Prosiding Seminar Nasional Pengembangan Teknologi Pertanian Politeknik Negeri Lampung (pp. 129-136). October 8, 2018. Lampung: Politeknik Negeri Lampung.

Pulighe, G., \& Lupia, F. (2020). Food first: COVID-19 outbreak and cities lockdown a booster for a wider vision on urban agriculture. Sustainability, 12(12), 1-4. https://doi.org/10.3390/su12125012

Rachmawati, D., \& Samidjan, I. (2013). The effect of substitution of fish meal with maggot meal in artificial feed for growth and survival rate of catfish. Saintek Perikanan: Indonesian Journal of Fisheries Science and Technology, 9(1), 62-67. https://doi.org/10.14710/ijfst.9.1.62-67

Roncarati, A., Gasco, L., Parisi, G., \& Terova, G. (2015). Growth performance of common catfish (Ameiurus melas Raf.) fingerlings fed mealworm (Tenebrio molitor) diet. Journal of Insects as Food and Feed, 1(3), 233-240. https://doi.org/10.3920/JIFF2014.0006

Swardana, A. (2020). Optimalisasi lahan pekarangan sebagai salah satu upaya pencegahan krisis pangan di masa pandemi covid-19. JAGROS, 4(2), 246-258. Retrieved from http://journal.uniga.ac.id/index.php/JPP/article/viewFile/922/771

Tiesnamurti, B. (2020). Prospek peternakan di era normal baru pasca pandemi covid-19: pemanfaatan berkelanjutan sumberdaya genetik ternak sebagai penyedia pangan hewani. Prosiding Seminar Teknologi Agribisnis Peternakan (STAP) Fakultas Peternakan Universitas Jenderal Soedirman, 7 (pp. 1-14). Purwokerto: Universitas Jenderal Soedirman.

Vos, R., Martin, W., \& Laborde, D. (2020). As COVID-19 spreads, no major concern for global food security yet. International Food Policy Research Institute Blog, 10. Retrieved August 21, 2020, from https://www.ifpri.org/blog/covid-19-spreads-no-majorconcern-global-food-security-yet

WHO. (2020). WHO corona virus (covid 19) dashboard. Retrieved August 21, 2020, from https://covid19.who.int/

Wicaksana, S. N., Hastuti, S., \& Arini, E. (2015). Performa produksi ikan lele dumbo (Clarias gariepinus) yang dipelihara dengan sistem biofilter akuaponik dan konvensional. Journal of Aquaculture Management and Technology, 4(4), 109-116. 
Zhang, S.-Y., Li, G., Wu, H.-B., Liu, X.-G., Yao, Y.-H., Tao, L., \& Liu, H. (2011). An integrated recirculating aquaculture system (RAS) for land-based fish farming: The effects on water quality and fish production. Aquacultural Engineering, 45(3), 93-102.

\section{Copyright and License}

This is an open access article distributed under the terms of the Creative Commons Attribution 4.0 International License, which permits unrestricted use, distribution, and reproduction in any medium, provided the original work is properly cited.

(C) 2020 Mojiono, Nur Qomariah, Fortunata Riana.

Published by LP3M of Universitas Mathla'ul Anwar Banten in collaboration with the Asosiasi Jurnal Pengabdian Kepada Masyarakat (AJPKM) 